\title{
Conflict Between Buleleng Government and Chandra Dwipa Company Concerning Construction of Green Spaces
}

\author{
I Gusti Ayu Apsari Hadi ${ }^{1}$, Komang Febrinayanti Dantes ${ }^{2}$ \\ \{apsari.hadi@gmail.com ${ }^{1}$, febrinayanti.dantes@undiksha.ac.id ${ }^{2}$ \}
}

Universitas Pendidikan Ganesha, Indonesia ${ }^{12}$

\begin{abstract}
This study aims to find the form of dispute settlement between Buleleng Government and the Chandra Dwipa Company concerning construction of Green Spaces Bung Karno Park in Singaraja. This research was held within 1 (one) year. The type of legal research using a empirical legal study with data collection by purposive sampling techniques through interviews, observation, documentation and literature studies. The subject of this research is Regional Government Buleleng, especially the Commiting Officer (PPK) Department of Housing, Settlement, and Land (Disperkimta), Buleleng Regency. The results show that (1) a contract clause/agreement letter between the Buleleng Government and Chandra Dwipa Company is in accordance with the principle of pacta sunt servanda; (2) the mechanism of dispute settlement of Green Spaces Bung Karno Park is the Contractor can't fulfill the project as planned then the government will ended up the work, imposition of penalties, and put the contractor on the black list.
\end{abstract}

Keywords : Disputes; Contract; Green Spaces; Bung Karno Park; Buleleng Regency.

\section{Introduction}

The existence of Green Spaces (RTH) become something important in a city. Apart from being designated as the lungs of the city, Green Spaces is also intended to anticipate the emergence of environmental problems in the future. Todays, the development of Green Spaces for environmental sustainability increasingly expanded by the public, private sector and local governments. Usually, the private sector will contribute in the form of Corporate Social Responsibility. Awareness from the public is usually carried out through environmentally conscious movements that can reduce damage to the environment itself[1].

The local government in this case has an important role in the development of Green Spaces as a manifestation of the environmental improvement program. The requirement for Green Spaces in urban areas is accordance to the mandate of Act Nr. 26 Year 2007 Concerning Spatial Planning, Article 1 Number 31 which states "Green Spaces is an area that extends / paths and / or groups, which use to more open in nature, a place to grow plants, both grow naturally and intentionally planted". It is also regulated that the requirement for Green Spaces in an urban area as regulated in Article 29 paragraph (2) states that the proportion of 
Green Spaces for urban areas is at least 30 percent of the total city area. This arrangement reaffirms the importance of balancing spatial planning, especially the existence of Green Spaces in urban areas[2].

Green Spaces development is a required program that must be carried out by the government because it is a mandate of the Act. In line with that, the government will doing their public functions from state administration. Van Vollenhoven argues that government action (Bestuurshandeling) is an action in the context maintaining of public by the state and the their people as spontaneously and independently by high and lowly authorities [3]. The government in administrative law as a body that given the authority to determine actions based on administrative law and therefore affect the circumstances or legal conditions of others or to implement some legal actions (based on Civil Law).

The various government functions as a government behavior (bestuurhandeling) in accordance with their authority are intended to cause a legal consequences in the administrative law or more simply the actions by state administrative officials in carrying out government affairs [4].

It should be notice that state administrative actions doesn't always have legal consequences for the society, because they are non-juridical (can't be legal consequences), however there are state administrative actions that have legal consequences (legal actions). According to Atmosudirjo, there are four kinds of state administrative law:

1) Decisions (beschikking, administrative discretion);

2) Plan (Plan);

3) Concrete Norms (concreto normgeving);

4) Pseudowetgeving.

By the various state administrative legal actions, the government here may make an act which doesn't have any legal consequences. Usually in a regional Spatial Planning which is based on Act Nr. 23 Year 2014 concerning Regional Government Article 12 paragraph (1) regions have obligations government affairs related to basic services, one of which is in the field of public works and spatial planning. So if the government is going to make a plan such as the construction of Green Spacse it is duties of the regional government, then very likely that the government will attach up with the private company in the line of an agreement contract.

The requirement for Green Spaces in urban areas according to the mandate of Act 26/2007 then regulated on a peculiarly regulation of the Minister of Domestic Affairs Nr. 1 Year 2007 concerning the Planning of Urban Green Spaces, thus mandating every city in the territory of Indonesia to build Green Spaces. Green Spaces is intended to support ecological, social, cultural, economic and aesthetic benefits. Unexception in Buleleng Regency, precisely in Singaraja City which in this case has an area about $27.98 \mathrm{~km} 2$. One of the Green Spaces that Singaraja City has it is Green Spaces Bung Karno Park, which is located in Sukasada District, Buleleng Regency. Bung Karno Park began construction in phase I in 2016 and until 2018 entered Phase III construction. The development of Green Spaces Bung Karno Park Phase III takes fund sourced from the Buleleng Regency APBD of IDR. 5,497,000,000, (Five billion four hundred and ninety seven million rupiah) and worked by the Contractor PT. Candra Dwipa.

The project construction of Green Spaces Bung Karno Park Phase III for 120 Calendar Days (24 August 2018 to 21 December 2018) due to the incomplete construction of the statue, the Contractor was given the opportunity to complete the work for 50 Calendar Days (22 December 2018 to 9 February 2019 ) with by imposition of penalties. However, until the opportunity to complete the over construction of the Green Spaces Bung Karno Park Phase III 
, the contractor has not been able to complete it. The impact of the unfinished work of the Bung Karno Statue, the Commitment Making Officer (PPK) terminated the contract unilaterally with a work progress of $74.932 \%$ of the contract value or equivalent to IDR. 4,119,012,040, - (four billion one hundred nineteen million twelve thousand and forty rupiah).

By observing all the pressures and desires from the Buleleng peoples through an audience with the Buleleng Regent (Friday 15 February 2019) and also hearing meeting with Commission II House of Representatives Regional Buleleng Regency (Monday, 18 February 2019), the construction of the Taman Bung Karno RTH Phase III can be continued and completed in 2019. Thus the authors will analyze the contract agreement between the Buleleng Regency Government and PT. Candra Dwipa through a research entitled, "Disputes Settlement Of Contract Between Buleleng Government And Chandra Dwipa Company Concerning Construction Of Green Spaces At Bung Karno Singaraja Park".

\section{Method}

This type of research is empirical legal studies with primary data and secondary data. Primary data collection techniques were obtained through observation and interviews. The research are consisting of 5 stages : Phase 1, the preparation, including literature study, making research instruments and applying for research permits. Stage 2, the research implementation, including the process of collecting primary data and secondary data. Primary data is interview with stakeholders the agreements maker, and secondary data is the form of the Bung Karno Park Agreement Letter in 2018. Stage 3, data processing which includes data on the contract dispute settlement mechanism for the construction of the Bung Karno Singaraja Green Spaces by the Buleleng Regency Government, analysis of the contents of the agreement letter which resulted in the inability to complete the construction of the Bung Karno Singaraja Park, as well as a strategic plan for reworking the construction of Bung Karno Singaraja Park. Stage 4, research data analysis using qualitative descriptive analysis. Stage 5, the preparation of a research report.

\section{Result and Discussion}

\section{Analysis Contract Clause Involving The Buleleng Government And PT. Candra Dwipa Regarding The Construction Of Green Spaces Bung Karno Park}

The government or state administration as a legal subject, or as a proponent of rights and obligations. As a legal subject, the government takes various actions, both real and legal. Real actions are actions that have no relevance to the law and therefore do not cause legal consequences, meanwhile legal actions based on their character can make particular legal consequences or can create rights and obligations [5] .

Administrative legal action is a statement of will that comes from an administrative body in special circumstances, intended to cause legal consequences in administrative law. Legal consequences that arise from legal action have consequences that are relevant to law such as: the creation of new legal relationships, companies or the termination of existing legal relationships [6]. Government actions in the field of public law are classified into two, namely:

1) One-sided public legal action: This legal action results directly from the government being committed to the act without waiting for a reaction from the affected parties; 
2) Two-sided public legal actions: This two-sided public legal action has legal consequences only after an agreement has been made between the government and the parties involved.

Besides taking action in the field of public law, the government, like an individual, as a legal subject can also take actions in the field of private law. This action is embodied in the quality of a legal entity acting on behalf of the institution not on behalf of a position[7].

One of the implementation legal action or two-sided public legal action is a contract / agreement made by the Buleleng Regency Government in this case implemented by DISPERKIMTA Buleleng Regency with a private company, namely PT. Chandra Dwipa in the construction of Green Spaces Bung Karno Park has been made out since 2018. This twosided public legal action is an action made by the government (not unilaterally), meaning that it involves other parties. They were obey to and enters into force of Civil Law regulation as well as the principle freedom of contract which binds the parties like any general agreement in common.

In civil law, correlation between the parties whose involved in the engagement to create rights and obligations which then give rise to the term achievement, which is something that is demanded by one of the parties to the other party. Each engagement is to give something, to do something, or not to do something as stated in the Civil Code. Based on this explanation, the engagement creates obligations to certain individuals or parties which can take the form one of the three forms, namely: (a) To give something away; (b) To do something; (c) To do nothing[8].

Agreement or verbintenis contains the meaning of a legal correlation between two or more people, which gives power to the right of one party to gain achievements and at the same time obliges the other party to fulfill achievements [9]. As stated in the Agreement Letter, the construction of Green Spaces Bung Karno Park according to the contract will last for 120 (one hundred and twenty) based on calendar days. However, until the time limit stated in the agreement between the two parties, PT. Chandra Dwipa could not fulfill his obligation to complete the making of the Bung Karno statue.

Based on the results of an interview with Putu Setyawati as the Commitment Officer (PPK) DISPERKIMTA (interview on July 20, 2020): based on the contract we agreed on (DISPERKIMTA as PPK and PT. Chandra Dwipa as the Provider) that the Provider agreed that the work would be completed in December 2018. Work as stated in Green Spaces Bung Karno Park Phase III Construction Agreement Letter Number: 600/1188 / RTH / 2018 (Attached), Article 2 states that the main scope of work consists of: (a) Preparatory work; (b) Bung Karno (Metal) Sculpture Pair Work; (c) Singa Ambara Raja Sculpture and Wall Sculpture Works; (d) Garden Work Type 3.

The Provider and PPK in the construction of the Green Spaces Bung Karno Park agreed that the contract implementation until the completion of the entire work is 120 (one hundred and twenty) calendar days. In the contract, it is stated that both the provider and the PPK have rights and obligations, including in Article 5, which means that the PPK has the right to supervise and inspect the work carried out by the Provider, request periodic reports on the implementation of work carried out by the Provider, provide facilities in the form of facilities and infrastructure required by the Provider for the smooth execution of the work, paying for the work according to a predetermined price. Meanwhile, the Provider has the rights and obligations to:

a. Receive payment for the performance of work at the price specified in the Contract;

b. Requesting facilities and infrastructure from PPK for the smoot it out execution of work in accordance with the provisions of the Contract; 
c. Report the implementation of work periodically to PPK;

d. report the implementation for use of domestic production / TKDN periodically to PPK;

e. To make and complete work in accordance with the work implementation schedule specified in the Contract;

f. To make and complete work carefully, accurately and responsibly by providing labor, materials, equipment, transportation to or from the field, and all permanent or temporary work required for the execution, completion and repair of the work specified in the Contract ;

g. Provide information needed for the inspection of implementation conducted by PPK;

h. Deliver the work results in accordance with the work delivery schedule stipulated in the Contract;

i. Take adequate steps such as implementing an Occupational Safety and Health Management System to protect the workplace environment, as well as limiting damage and disturbance to the community and property due to the activities of the Provider.

The agreement is an occation where someone promises to another person or it can be said a moment where two or more people pledge themselves to do something. The definition of the boundary agreement has been regulated in Article 1313 of the Civil Code which states that an agreement is an act whereby one or more people bind themselves to one or more other people. The agreement made between the government and the private sector is no exception, in this case it must be in accordance with the elements in an agreement, namely:

a. There are parties

b. There is a consensus or agreement from the parties

c. The object in the agreement is an materials

d. There is a material purpose regarding assets

e. There are certain forms, both orally and in writing

f. There are certain conditions

The elements of the agreement then contained in the agreement between the parties, especially between the DISPERKIMTA and PT. Chandra Dwipa and it must be implemented in accordance with the principles applicable in the legal agreement when it comes to a dispute, such as default or non-completion of work

\section{The Dispute Settlement Mechanism Construction of The Green Spaces Bung Karno Between Buleleng Government and PT. Chandra Dwipa.}

Disputes originate from the dissatisfaction of certain parties with the things that has been done by certain other parties. This dissatisfaction occurs because of the hope that the other party will fulfill or create a required condition. This is come from a person's rights to force someone else to give something, do something or do nothing action. This rights arises because there are other parties who have agreed to fulfill their expectations. This is usually regulated in a contract or agreement where the parties are binding to each other and perform achievements.

Article 1338 Paragraph (1) of the Civil Code, states that all agreements made legally are valid as law for those who make them. An agreement cannot be withdrawn apart from the agreement of the two parties, the agreement is not only binding for the things that are expressly stated in it, but also for everything that is according to the characteristic of the agreement. The consequences of an agreement are as follows [10] :

1. The Agreement Only Valid Between The Parties That Made It (Article 1340 Paragraph (1) of the Civil Code). 
2. Regarding Cancellation or Nulitas in the Agreement (Article 1320 of the Civil Code). The following are the kinds canceled, namely:

a. The agreement can be canceled (Articles 1330 to 1331 Civil Code).

b. Agreement is null and void

c. Relative Cancellation and Absolute Cancellation

In accordance with the meaning of the principle of pacta sunt servanda (Article 1338 Paragraph (1) Civil Code) which means that every agreement made is binding on the parties that make and applies as a law for the parties. Based on the contents of the Green Spaces Bung Karno Park Phase III Construction Agreement Letter Number: 600/1188 / RTH / 2018 in Article 6, the contract period starts from the contract signing date until the maintenance period ends. The contract period is effective as of the date specified in the Special Conditions of Contract and the completion of the entire work for 120 (one hundred and twenty) calendar days. Estimated work of making Green Spaces Bung Karno Park starting on August 24, 2018 until the end of 120 calendar days is until December 21, 2018.

In the implementation the construction of Green Spaces Bung Karno Park, the PPK supervised the realization of RTH Bung Karno Park. Regarding to the rights to supervise that is owned by PPK if the Provider does not perform the work as specified in the contract, the PPK can take actions such as issuing a warning letter. As was done by the PPK to the contractor, namely giving a warning letter I to the Provider who was nearing the end of the work but the realization yet didn't match as much as accordance with the plan to build Green Spaces Bung Karno Park.

In accordance with the interview, the PPK gave a warning letter number 600/2045 / PPK / RTH / 2018 address to the Director of PT. Chandra Dwipa, which contains the following points:

1. The construction of RTH Taman Bung Karno has entered its 17th week (14 December 21 December 2018).

2. Work Supervisory Consultant Report for the 16th week (7 to 13 October 2018) plan $43.913 \%$, realization $5.682 \%$, deviation $-38.231 \%$.

3. By the time that the remaining work execution until the end of the contract on December 21,2018 is 7 calendar days (point 1 ).

4. By observed at the physical condition, there are still a lot of work that has not been completed,

5. In accordance with the points above, the contractor is warned to immediately take steps in completing the work by:

a. Increase the work force;

b. Increase working time / hours;

c. Sending work items that have been done at Hima Gallery Yogyakarta as a subcontractor.

6. In order to commit to completing the work, the contractor must submit an application letter for the opportunity to complete the work before the end of the contract (21 December 2018) with a statement that contains:

- The ability to complete work (by providing the opportunity to complete the work and imposition of penalties);

- To add 50 calendar days of implementation guarantee (until 23 February 2019) and down payment guarantee (up to 23 February 2019).

With that warning letter, based on the contract the Provider agreed to requests the opportunity to extend the work construction period for 50 calendar days, namely until February 23, 2019. 
Th extra time of work construction is marked by a changes (addendum) to the agreement letter. This is in accordance with what is stated in the General Terms of Contract: B.4 Addendum 36. Change of Contract: The contract can only be changed through a contract addendum. Based on these provisions, an Addendum to Letter of Agreement Number: 600/2080 / RTH / 2018 was made on 19 December 2018 from Letter of Agreement Number: 600/1188 / RTH / 2018 Date: 24 August 2018 which contains the principle changing contract clause which originally contained, " Implementation period according to point E in CHAPTER $\mathrm{X}$ The Special Conditions of Contract (SSKK). Implementation period for: 120 (one hundred and twenty) calendar days from the date of commencement of work listed in the SPMK. Meanwhile, the amendment of the agreement becomes: Implementation period for: 170 (one hundred and seventy) calendar days from the date based on the listed in SPMK. Given the opportunity to complete the work of 50 (fifty) calendar days up to 9 (nine) February 2019 with a penalty for late payment for each day of delay, which is $1 / 1000$ (one thousandth) of the total contract value before PPN. Provider is willing to extend the implementation guarantee until February 9 (nine) 2019.

As the validity of the new contract between DISPERKIMTA Buleleng and the Contractor PT. Chandra Dwipa is approaching the end of the additional 50 calendar days the progrees work construction still wasn't in accordance with stated in the agreement. Based on the Monev Report of the Green Spaces Sector Staff DISPERKIMTA Buleleng, the process of making the Bung Karno Statue did not match with statement from the contractor. Meanwhile, there are 11 reliefs (stories) that have not been completed was made in several workshops at Hima Gallery Yogayakarta as a sub-contractor.

Following up to results of Monev by Green Spaces field staff, they were given warnings. PPK issued Letter Number: 600/272 / RTH / 2018 addressed to the Provider, in this case the Contractor of PT. Chandra Dwipa, which contains a warning that the work completion time is only 8 calendar days (1 February 2019 - 9 February 2019). In addition, the PPK also instructs providers to make strategic steps in completing work by increasing the workforce and increasing work time / hours (overtime) as well as paying attention to the availability of building materials in the field.

"If by 9 February 2019 the work has not been completed, we will deciding to terminate the contract and impose a blacklisting sanction in accordance with the applicable provisions", the results of the interview with the DISPERKIMTA PPK."

In the process of finalizastion remaining work by the contractor and also the sculptor in Yogyakarta, the facts it could not be completed. In this case the contractor and subcontractor have violated the principle of good faith (Article 1338 of the Civil Code) that applies in the agreement[11]. The commitment made by the sculptor and partners to complete the Bung Karno Statue and the reliefs until February 8, 2019 and continue to send it to Singaraja on February 9, 2019 at the latest is not proven, because it is approaching the end of the contract (50 days) to work on the statues and reliefs it is not done yet.

Due to this condition, the PPK took decisive action by terminating work activities. In line with the termination of work activities in the construction of RTH Taman Bung Karno, the PPK issued a Contract Termination Letter Number: 600 / 324.6 / RTH / 2019 dated 10 February 2019 which was addressed to the Director of PT. Chandra Dwipa as the Provider.

According to Article 1381 of the Civil Code, the abolition of an agreement can occur due to several reasons, one of which is the failure to fulfill the conditions for the birth of an agreement (as one of the sources of the engagement). In this case, it can be said that the contractor or provider are unable to fulfill the obligations as stated in the contract so that it is considered to have defaulted in the contract. The legal consequence of this act of default was 
that the PPK of Buleleng Regency which was carried out by DISPERKIMTA decided to terminate the work. In addition the agreement become null ann void. The contractor is also impositions of penalties in accordance with the applicable contract and included the provider into the black list.

\section{Conclusion}

The contract / agreement for the development of Green Spaces Bung Karno Park between the Buleleng Government who made by DISPERKIMTA Buleleng and the private company, namely PT. Candra Dwipa ended up with null and void agreement. It based on the PPK Termination Letter of Contract Agreement Number: 600 / 324.6 / RTH / 2019 took firm action by terminating work activities in the construction of Green Spaces Bung Karno Park. The contractor is also impositions of penalties in accordance with the applicable contract and included the provider into the black list.

\section{References}

[1] A. C. K. Lee, H. C. Jordan, and J. Horsley, "Value of urban green spaces in promoting healthy living and wellbeing: Prospects for planning," Risk Management and Healthcare Policy. 2015, doi: 10.2147/RMHP.S61654.

[2] World Health Organization, "Urban green spaces: A brief for action," Reg. Off. Eur., 2017.

[3] N. Aisyah, "The Existence of Citizens Legal Protection Against Government Actions in Making State Administration Decisions," Ocean Justice J. Law, vol. 11, no. 1, p. 46, 2016.

[4] J. Jefry Pietersz, "the abuse of power from Good Governance Principles," SASI, vol. 23, no. 2, pp. 167-188, 2018, [Online]. Available: https://doaj.org/article/6c8d579afeef4e428b7d34b6e1cdb417.

[5] M. I. P. Jashari, "The Role of the Principle of Transparency and Accountability in Public Administration," Acta Univ. Danubius Adm., vol. 10, no. 1, pp. 60-69, 2018, [Online]. Available: https://doaj.org/article/b450da7293d54241ad910ff94ebe471f.

[6] R. HR, State Administrative Law. UII Press, 2002.

[7] A. et. al Fuji., Governance Law. Open University Publishing Center, 2004.

[8] A. Hartkamp, "Principles of Contract Law," in Towards a European Civil Code, 2004.

[9] H. M. Yahya, Aspects of Agreement Law. Alumni Publishers, 1986.

[10] Muljadi. Kartini, The Engagement That Born From The Agreement. PT Raja Grafindo Persada, 2006.

[11] C. E. Dawkins, "The Principle of Good Faith: Toward Substantive Stakeholder Engagement," J. Bus. Ethics, 2014, doi: 10.1007/s10551-013-1697-z. 